\title{
Environmental Science in Building
}


Macmillan Building and Surveying Series

Series Editor: Ivor H. Seeley

Emeritus Professor, Trent Polytechnic

Advanced Building Measurement, second edition Ivor $\mathrm{H}$. Seeley An Introduction to Building Services Christopher A. Howard Applied Valuation Diane Butler Asset Valuation Michael Rayner Building Economics, third edition Ivor H. Seeley Building Maintenance, second edition Ivor H. Seeley Building Quantities Explained, fourth edition Ivor H. Seeley Building Surveys, Reports and Dilapidations Ivor H. Seeley Building Technology, third edition Ivor $\mathrm{H}$. Seeley Civil Engineering Contract Administration and Control Ivor H. Seeley Civil Engineering Quantities, fourth edition Ivor H. Seeley Civil Engineering Specification, second edition Ivor H. Seeley Contract Planning and Contractual Procedures B. Cooke Contract Planning Case Studies B. Cooke Environmental Science in Building, second edition R. McMullan Introduction to Valuation D. Richmond Principles of Property Investment and Pricing W. D. Fraser Quantity Surveying Practice Ivor H. Seeley Structural Detailing P. Newton Urban Land Economics and Public Policy, fourth edition P. N. Balchin, J. L. Kieve and G. H. Bull 1980 JCT Standard Form of Building Contract, second edition

R. F. Fellows 


\section{Fnvironmental}

Science in

\section{Building}

\section{R. McMullan}

MSc, CPhys, MInstP, MCIOB

Second Edition

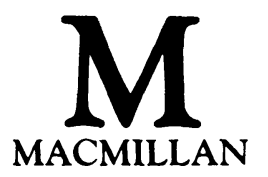


All rights reserved. No reproduction, copy or transmission of this publication may be made without written permission.

No paragraph of this publication may be reproduced, copied or transmitted save with written permission or in accordance with the provisions of the Copyright Act 1956 (as amended), or under the terms of any licence permitting limited copying issued by the Copyright Licensing Agency, 33-4 Alfred Place, London WC1E 7DP.

Any person who does any unauthorised act in relation to this publication may be liable to criminal prosecution and civil claims for damages.

First published 1983

Reprinted 1985, 1987, 1988

Second edition 1989

Published by

MACMILLAN EDUCATION LTD

Houndmills, Basingstoke, Hampshire RG21 2XS

and London

Companies and representatives

throughout the world

McMullan, R. (Randall)

Environmental science in building.-

2nd ed.

1. Buildings Engineering services

I. Title

696

ISBN 978-0-333-49117-1 ISBN 978-1-349-19896-2 (eBook)

DOI 10.1007/978-1-349-19896-2 


\section{Contents}

Preface

Acknowledgements

Introduction

1 Principles of Heat 5

Nature of heat $\quad 5$

$\begin{array}{ll}\text { Heat transfer } & 15\end{array}$

$\begin{array}{lr}\text { Gases and vapours } & 18\end{array}$

$\begin{array}{ll}\text { Exercises } & 22\end{array}$

2 Thermal Insulation $\quad 23$

Insulating materials $\quad 23$

$\begin{array}{ll}U \text {-values } & 27\end{array}$

$\begin{array}{ll}\text { Structural temperatures } & 38\end{array}$

$\begin{array}{ll}\text { Exercises } & 40\end{array}$

3 Thermal Environment $\quad 43$

$\begin{array}{lr}\text { Thermal comfort } & 43\end{array}$

Heat losses $\quad 48$

Heat gains $\quad 53$

Energy consumption $\quad 57$

$\begin{array}{ll}\text { Exercises } & 64\end{array}$

4 Humidity, Condensation, Refrigeration 66

Humidity $\quad 66$

$\begin{array}{ll}\text { Condensation in buildings } & 75\end{array}$

$\begin{array}{ll}\text { Condensation conditions } & 79\end{array}$

Refrigerators and heat pumps $\quad 86$

$\begin{array}{ll}\text { Exercises } & 90\end{array}$

5 Principles of Light $\quad 92$

Electromagnetic radiation $\quad 92$

$\begin{array}{ll}\text { Nature of vision } & 94\end{array}$

Measurement of lighting $\quad 97$

$\begin{array}{lr}\text { Colour } & 107\end{array}$

Exercises $\quad 111$ 
6 Artificial Lighting $\quad 112$

$\begin{array}{ll}\text { Lamps } & 112\end{array}$

$\begin{array}{ll}\text { Luminaires } & 117\end{array}$

$\begin{array}{ll}\text { Lighting design } & 121\end{array}$

$\begin{array}{ll}\text { Exercises } & 127\end{array}$

7 Natural Lighting $\quad 128$

$\begin{array}{ll}\text { Natural light sources } & 128\end{array}$

$\begin{array}{ll}\text { Daylight factors } & 131\end{array}$

$\begin{array}{ll}\text { Combined lighting } & 138\end{array}$

$\begin{array}{ll}\text { Exercises } & 140\end{array}$

8 Principles of Sound $\quad 141$

$\begin{array}{ll}\text { Nature of sound } & 141\end{array}$

$\begin{array}{ll}\text { Sound levels } & 146\end{array}$

Attenuation of sound 153

$\begin{array}{ll}\text { Nature of hearing } & 157\end{array}$

$\begin{array}{ll}\text { Exercises } & 160\end{array}$

9 Noise $\quad 162$

$\begin{array}{ll}\text { Measurement of noise } & 162\end{array}$

$\begin{array}{ll}\text { Noise control } & 168\end{array}$

$\begin{array}{ll}\text { Sound insulation } & 170\end{array}$

$\begin{array}{ll}\text { Exercises } & 181\end{array}$

10 Room Acoustics $\quad 183$

$\begin{array}{ll}\text { General principles } & 183\end{array}$

$\begin{array}{ll}\text { Reflection } & 184\end{array}$

$\begin{array}{ll}\text { Absorption } & 187\end{array}$

Reverberation $\quad 192$

$\begin{array}{ll}\text { Exercises } & 198\end{array}$

11 Electricity $\quad 200$

$\begin{array}{ll}\text { Current electricity } & 200\end{array}$

$\begin{array}{ll}\text { Magnetism } & 213\end{array}$

$\begin{array}{ll}\text { Induction } & 218\end{array}$

$\begin{array}{ll}\text { Power supplies } & 227\end{array}$

$\begin{array}{ll}\text { Exercises } & 233\end{array}$

12 Water Supplies $\quad 235$

Fluids at rest $\quad 235$

$\begin{array}{ll}\text { Fluid flow } & 239\end{array}$

$\begin{array}{ll}\text { Natural waters } & 248\end{array}$

Water treatment $\quad 255$

$\begin{array}{ll}\text { Exercises } & 261\end{array}$ 
Conclusion

Useful References

Index 


\section{Preface}

This book studies the science of those services that contribute to the environment which exists in and around buildings. The main topics are heating, lighting and sound in buildings; and the supply of electricity and water to buildings. Although some subjects have to be introduced separately the text emphasises the necessity of an integrated approach to the study and design of environmental services.

The book is intended for students of building, civil engineering and surveying who are studying environmental science. The requirements of courses for degrees, for examinations of professional institutions, and for Technician Education Council awards should be satisfied by the contents of the book. It will also serve as a useful reference book for those in professional practice and for anyone interested in a knowledge of environmental science.

The motivation for the book stems from continuing teaching experience with many students and information is presented in a manner that has been found popular and successful. Topics are developed from basic principles and assume the minimum prior knowledge of science and mathematics. Important facts and formulae are highlighted in the text as an aid to reference and to memory. Definitions and units are introduced in a consistent form using recommended units and, where a numerical approach is relevant, worked examples are displayed step-by-step and supported by exercises for practice. The style of writing has been kept simple but, at the same time, it has a technical content and accuracy appropriate to this level of study. The text is illustrated by labelled drawings which are intended to help explain the text and to act as models for student sketches.

I wish to thank my colleagues and students who contributed, consciously or otherwise, to the book, and to give special thanks to Mrs A. McMullan who typed so much at such a distance.

R. McMullaN 


\section{Acknowledgements}

The author and publishers thank the following organisations for permission to quote from their material, as detailed below:

CIBS Guide used for tables 2.1 and 2.5; CIBS Code of Interior Lighting used for tables 6.2 and 7.1: by courtesy of the Chartered Institute of Building Services.

BRE Digest 42 used for table 7.2; BRE Daylight Protractors used for figures 7.5 and 7.6: by courtesy of the Director, Building Research Establishment and by permission of the Controller, HMSO. 